\title{
Differences in circulating corticosterone levels associated with elevation of breeding sites in Rufous-collared Sparrows Zonotrichia capensis
}

\author{
Yanina Poblete ${ }^{1,2} \cdot$ Victor Gutierrez $^{1} \cdot$ Paulina L. González-Gómez ${ }^{3,4} \cdot J^{\prime}$ ohn C. Wingfield ${ }^{3} \cdot$ Rodrigo A. Vásquez $^{1}$
}

Received: 1 April 2020 / Accepted: 14 November 2020 / Published online: 3 December 2020

(c) The Author(s) 2020

\begin{abstract}
To facilitate breeding and any energetically costly activity, individuals of the same species can substantially vary their circulating corticosterone (CORT) levels to cope with local environmental conditions at different elevations. We compared baseline and the stress-induced plasma CORT levels during the parental care stage between free-living Rufous-collared Sparrows (Zonotrichia capensis) that breed at high $(\sim 2500 \mathrm{~m})$ and low $(\sim 500 \mathrm{~m})$ elevations in central Chile. We found that baseline CORT levels at different elevations were similar and that stress-induced levels were significantly lower in birds breeding at high elevation; however, we detected no sexual dimorphism in CORT levels related to elevation. We found that larger individuals had higher stress-induced CORT levels at low elevation regardless of sex. Our results show that environmental conditions at high elevation seem to be not severe enough to promote more elevated baseline CORT levels. However, breeding Rufous-collared Sparrow must still deal with both shorter breeding seasons and increased exposure to unpredictable events. Thus, a reduced stress response during the parental care stage would be more favorable for supporting breeding activities at high elevations. Future studies should focus on describing the life-history traits of these populations and the effects that other stressors, such as predation pressure and food availability, may have on the adrenocortical response in these environments to evaluate the consequences for survival and reproductive success. This information is important for enhancing our understanding of the ecological and evolutionary mechanisms that modulate variation in the adrenocortical response among populations of the same species.
\end{abstract}

Keywords Altitudinal differences $\cdot$ Adrenocortical stress response $\cdot$ Zonotrichia capensis $\cdot$ Southern Andes

Communicated by L. Fusani.

Electronic supplementary material The online version of this article (https://doi.org/10.1007/s10336-020-01846-w) contains supplementary material, which is available to authorized users.

Yanina Poblete

yaninapobleteq@gmail.com

1 Instituto de Ecología y Biodiversidad, Departamento de Ciencias Ecológicas, Facultad de Ciencias, Universidad de Chile, Las Palmeras 3425, Nuñoa, Santiago, Chile

2 NIAVA: Núcleo de Investigaciones Aplicadas en Ciencias Veterinarias y Agronómicas, Instituto de Ciencias Naturales, Universidad de Las Américas, Av. Manuel Montt 948, Providencia, Santiago, Chile

3 Department of Neurobiology, Physiology and Behavior, University of California, One Shields Avenue, Davis, CA 95616, USA

4 Universidad Autónoma de Chile, Av. Pedro de Valdivia 425, Providencia, Santiago, Chile 


\section{Zusammenfassung}

Um das Brüten und überhaupt jede energetisch kostspielige Aktivität zu erleichtern, können Individuen derselben Art ihre Kortikosteronspiegel (CORT) erheblich verändern, um so mit den jeweiligen örtlichen Umweltbedingungen in verschiedenen Höhenlagen zurechtzukommen. Wir verglichen die Basiswerte und die stressbedingten CORT-Werte während der Zeit der Aufzucht zwischen in Zentralchile in hohen (ca. $2500 \mathrm{~m}$ ) und tiefen (ca. $500 \mathrm{~m}$ ) Lagen brütenden freilebenden Morgenammern (Zonotrichia capensis). Dabei fanden wir, dass die Basis-CORT-Werte in den verschiedenen Höhenlagen ähnlich, die stressbedingten Werte der in hohen Höhenlagen brütenden Vögel aber signifikant niedriger waren; Unterschiede zwischen den Geschlechtern gab es nicht. Ferner fanden wir, dass größere Tiere unabhängig von ihrem Geschlecht in niedrigeren Höhenlagen höhere stressbedingte CORT-Werte aufwiesen. Unsere Ergebnisse zeigen, dass die Umweltbedingungen in großer Höhe offenbar nicht schwerwiegend genug sind, um höhere CORT-Basiswerte hervorzurufen. Aber dort brütende Morgenammern müssen mit kürzeren Brutzeiten zurechtkommen und sind unvorhersehbaren Geschehnissen stärker ausgesetzt. Deshalb wäre während der elterlichen Nrutpflege eine schwächere Stressreaktion für die Brutaktivitäten in größeren Höhenlagen günstig. Künftige Untersuchungen sollten sich auf die Beschreibung der Life-history-Eigenschaften dieser Populationen konzentrieren und darauf, was für Auswirkungen andere Stressfaktoren wie z. B. Räuber und Nahrungsverfügbarkeit in diesen Umweltgegebenheiten auf die adrenokortikalen Reaktionen möglicherweise haben, um die Folgen für das Überleben und den Fortpflanzungserfolg einschätzen zu können. Diese Informationen sind für ein besseres Verständnis derjenigen ökologischen und evolutionären Mechanismen wichtig, die bei Populationen derselben Art die Veränderungen der adrenokortikalen Reaktionen modulieren.

\section{Introduction}

Corticosterone (CORT) is a steroidal hormone that plays a key role in responses to environmental variability, because it modulates the energy balance facilitating both physiological and behavioral changes needed for different life-history stages in the birds (Sapolsky et al. 2000; McEwen and Wingfield 2003; Romero 2002; Landys et al. 2006). Baseline CORT levels allow individuals to respond to predictable energetic demands, such as daily and seasonal temperature variation, breeding and daily activities (Romero et al. 2009; Bonier et al. 2009; Welcker et al. 2015).

On the other hand, CORT levels induced by unpredictable events (i.e., predation threats, starvation, inclement weather, and handling; Romero and Wingfield 2016) are driven by the adrenocortical stress response triggering a cascade effect: the hypothalamus secretes arginine vasotocin and corticotropin-releasing factor, which, in turn, activate the anterior pituitary release of adrenocorticotropin (ACTH), stimulating the synthesis and secretion of CORT by adrenal glands (Romero and Remage-Healey 2000; Romero and Wingfield 2016) resulting in plasma CORT levels significantly higher than those expressed during daily life predictable events (i.e., baseline CORT levels) (Romero, 2004; Landys et al. 2006). The adrenocortical stress response is considered a facultative emergency response that allows rapid physiological and behavioral modifications to promote survival facing unpredictable stressful events (Sapolsky et al. 2000; Landys et al. 2006); hence, modulating this response is crucial for mediating evolutionary trade-offs between individual survival and reproduction, particularly for individuals that breed in environments where unpredictable events are common (Romero and Wingfield 2016).
High elevation habitats are especially challenging environments for breeding birds because of the often unpredictable changes in weather conditions (Addis et al. 2011). Comparative studies have shown that at high elevations in temperate zones of the Northern Hemisphere, birds often down-regulate their adrenocortical stress response during parental care (Bears et al. 2003; Breuner and Hahn 2003; Pereyra and Wingfield 2003), possibly to reduce negative effects of the stress response, such as nest abandonment (Romero et al. 2000). In contrast, tropical Rufous-collared Sparrows breeding at high elevation show higher sensitivity to stress during parental care compared to their northern congeners (Breuner and Hahn 2003), suggesting duration of the breeding season, temperature and life-history traits may play a role in the modulation of the adrenocortical stress response to cope effectively with local environmental conditions (Wada et al. 2006). Whether the adrenocortical stress response is down-regulated at high elevations in the temperate zones of the Southern Hemisphere during parental care is unclear because this issue has been comparatively understudied (but see Clark et al. 2019).

The elevation gradient of the Andes in Central Chile presents an ideal scenario to compare circulating CORT levels between birds that breed at different elevations. In this region, the mean annual precipitation varies from 300 to $400 \mathrm{~mm}$ in the lowlands ( $500 \mathrm{~m}$.a.s.1.) to $500-900 \mathrm{~mm}$ at high elevations ( 2500 m.a.s.l.). In addition, at high-elevation localities, the air temperature is $\sim{ }^{\circ} \mathrm{C}$ (minimum) and $\sim 10{ }^{\circ} \mathrm{C}$ (maximum monthly mean) lower than in the lowlands, contributing to the formation of snow cover at high elevations (Stehr and Aguayo 2017; Barria et al. 2019; Viale and Nuñez 2011). Rufous-collared Sparrows (Zonotrichia capensis), a common passerine species in Central Chile, 
present populations which breed across this gradient from sea level to $>4000$ m.a.s.l. Individuals at low elevations are resident year-round (Poblete et al. 2018), and present long breeding seasons, possibly producing multiple clutches per year (Couve et al. 2016). In contrast, at high elevations, the breeding season is shorter, probably with no more than two clutches per year (Wingfield et al. 1995). Despite harsh environmental conditions during the winter at high elevations (Di Castri and Hajek 1976), this species does not migrate downslope and instead remains at the same elevations in refuge habitats during the winter (Poblete et al. 2018).

In this study, we compared circulating CORT levels between individuals of Rufous-collared Sparrow breeding at high $(\sim 2500 \mathrm{~m})$ and low $(\sim 500 \mathrm{~m})$ elevation in central Chile during the parental care stage. We hypothesize that climatic conditions at high elevations may be severe enough to promote higher baseline CORT levels and lower stressinduced CORT levels in individuals in parental care stage, thus reducing the likelihood of nest abandonment.

\section{Methods}

\section{Species and study sites}

Rufous-collared Sparrow is a generalist species that occurs from southern Mexico to the southern tip of South America (Chapman 1940). It is mainly granivorous but also may forage for fruits and insects depending on their environmental availability (Lopez-Calleja 1995). This species is socially monogamous, and although males generally do not incubate, they do show bi-parental care when feeding nestlings. Sexual dimorphism is not obvious, but sexes can be differentiated during the breeding season through the cloacal protuberance (CP) in males and the brood patch (BP) in females (Chapman 1940; Miller and Miller 1968).

Field work was conducted at two study sites located at high (Farellones; $33^{\circ} 21^{\prime} \mathrm{S}, 70^{\circ} 17^{\prime} \mathrm{W}, 2500-2700 \mathrm{~m}$ ) and low (Picarquín; 33 $3^{\circ} 57^{\prime} \mathrm{S}, 70^{\circ} 37^{\prime} \mathrm{W}, 500 \mathrm{~m}$ ) elevations in central Chile. Descriptions on climate differences between both study locations were based on data available from the Center for Climate and Resilience Research (2020) (Fig. 1). For instance, between 1978 and 2019, differences between low and high elevations include $300.7 \mathrm{~mm}$ in the accumulated annual precipitation (high: $608.11 \pm 335.52 \mathrm{~mm}$; low: $307.41 \pm 152.65 \mathrm{~mm}$; Fig. 1a), $4.7^{\circ} \mathrm{C}$ in the mean annual minimum temperature (high: $3.99 \pm 0.70{ }^{\circ} \mathrm{C}$; low: $8.69 \pm 0.45{ }^{\circ} \mathrm{C}$; Fig. 1 b), $9.22^{\circ} \mathrm{C}$ in the mean annual maximum temperature (high: $13.78 \pm 0.73{ }^{\circ} \mathrm{C}$; low: $23.00 \pm 0.60{ }^{\circ} \mathrm{C}$; Fig. $1 \mathrm{c}$ ), and snow cover present from $2000 \mathrm{~m}$, mainly in the winter (Saavedra et al. 2018). During the study year (2010), similar patterns were observed, with differences of $284.5 \mathrm{~mm}$ in the accumulated monthly precipitation (high: $445.5 \pm 49.82 \mathrm{~mm}$; low: $161 \pm 17.10 \mathrm{~mm}$; Fig. $1 \mathrm{~d}), 4.17^{\circ} \mathrm{C}$ in the mean monthly minimum temperature (high: $3.01 \pm 4.83{ }^{\circ} \mathrm{C}$; low: $7.18 \pm 4.15^{\circ} \mathrm{C}$; Fig. 1e), and $9.08{ }^{\circ} \mathrm{C}$ in the mean monthly maximum temperature (high: $13.78 \pm 6.57{ }^{\circ} \mathrm{C}$; low: $22.86 \pm 5.89^{\circ} \mathrm{C}$; Fig. 1f), indicating that the weather at high elevation was harsher than that at low elevation in this region.

\section{Assessment of the parental care stage (mid-breeding)}

Rufous-collared Sparrows were captured using mist nets between 7:00 and 12:00 p.m. from 2 to 10 November at the low elevation site (Picarquín $33^{\circ} 57^{\prime} \mathrm{S}, 70^{\circ} 37^{\prime} \mathrm{W}, 500 \mathrm{~m}$; $n=10)$ and from 3 to 10 December at the high-elevation site (Farellones $33^{\circ} 21^{\prime} \mathrm{S}, 70^{\circ} 17^{\prime} \mathrm{W}, 2500-2700 \mathrm{~m} ; n=12$ ) in 2010. Sampling dates were determined based on the standardized observations recommended by Clark et al. (2019) to maximize the probability of sampling individuals when they were expressing parental care behavior (mid-breeding) in the breeding season. Each individual was considered to be in the parental care stage if females had edematous or wrinkled BPs (scores ranging from 3 to 4), males had CP lengths greater than $5 \mathrm{~mm}$, chicks were present in the nests and/or the parents were feeding offspring.

\section{Morphological measures and sexing}

Birds were banded with individual metal bands (National Band and Tag Co., Newport, Kentucky, USA and Split Metal Bird Rings, Porzana Ltd., UK). We also measured tarsus length and body mass to estimate a body condition index using residuals from the regression of chick body mass on tarsus length (LormÉe et al. 2003; supplementary material table A1). The sex was assigned by visually examining the $\mathrm{CP}$ in males and BP in females (Miller A.H and Miller V.D. 1968).

\section{Blood sampling and Corticosterone analyses}

Blood samples were obtained by puncturing the brachial vein using a 26-gauge needle and heparinized microhematocrit tubes at 3,15 and $30 \mathrm{~min}$ after capture, to measure the CORT baseline (mean $109 \mathrm{~s}$ ) and stress response (15 and $30 \mathrm{~min}$ ) during handling. Blood collected amounted to less than $1 \%$ of the bird's mass (Breuner et al. 1999). Samples were stored on ice for a maximum of $5 \mathrm{~h}$ before centrifugation and separation of the blood plasma from red blood cells. The plasma was aspirated with a Hamilton syringe and frozen $\left(\right.$ at $-20{ }^{\circ} \mathrm{C}$ ) until they were transported on dry ice to the University of California, Davis, to assay for the total CORT content in each sample. 

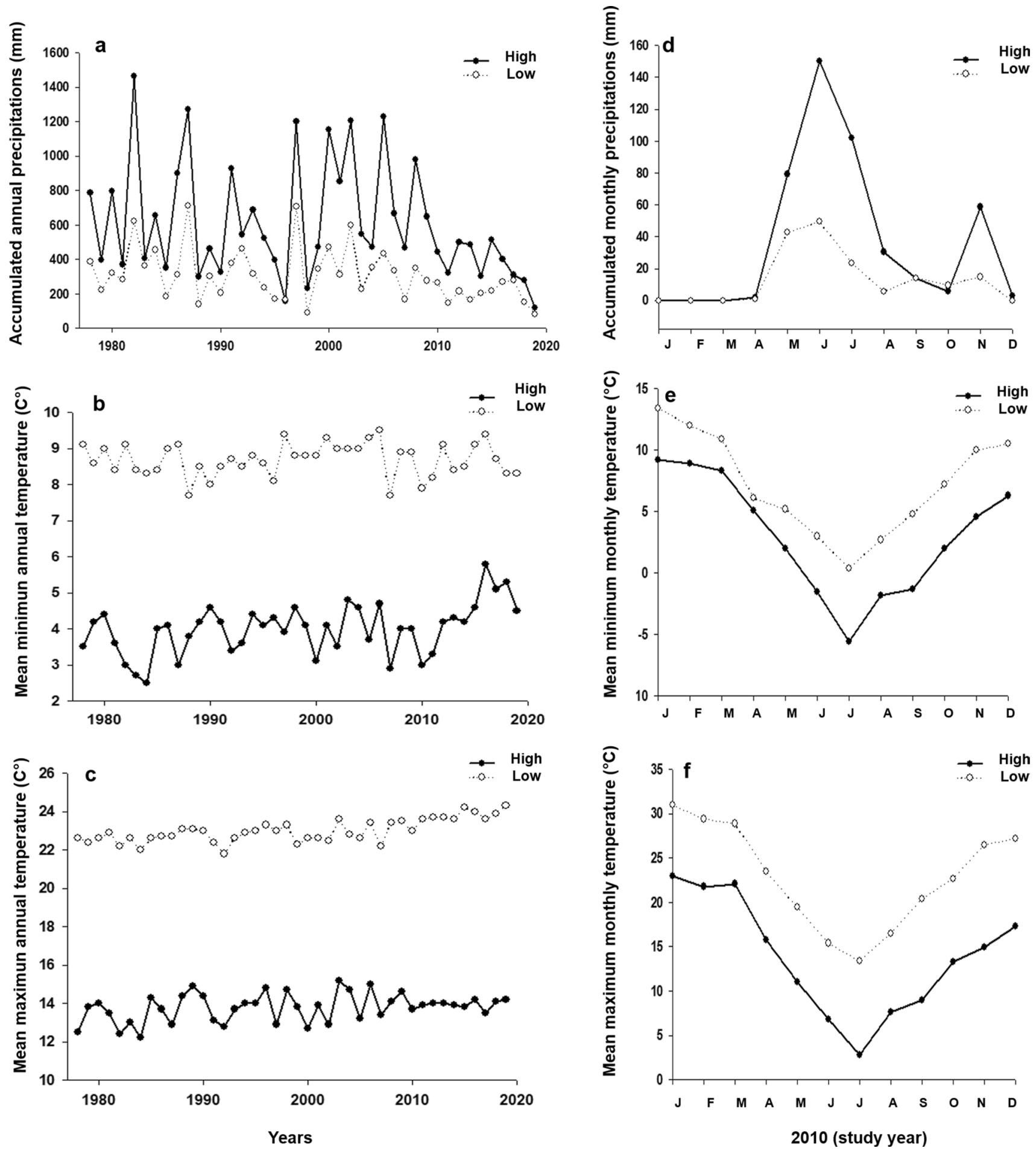

Fig. 1 Precipitation and temperature trend at high $(\sim 2500 \mathrm{~m})$ and low $(\sim 500 \mathrm{~m})$ elevations in central Chile. Figure shows patterns of 31-year (left) in a annual accumulated precipitation, b mean minimum annual temperature, and $\mathbf{c}$ mean maximum annual temperature;

CORT concentrations in plasma were determined using direct radioimmunoassay (Wingfield et al. 1995). To determine the efficiency of hormone extraction from the plasma, and patterns of the study year (right) in $\mathbf{d}$ monthly accumulated precipitation, e mean minimum monthly temperature, and $\mathbf{f}$ mean maximum monthly temperature, respectively

$20 \mu \mathrm{L}$ of $2000 \mathrm{cpm}$ of tritiated CORT was added to all samples and incubated overnight. Hormones were extracted from the plasma using freshly redistilled dichloromethane. 
The aspirated dichloromethane phase was evaporated using a stream of nitrogen at $45{ }^{\circ} \mathrm{C}$. Samples were then reconstituted in phosphate-buffered saline with gelatin. All samples were run in duplicate; intra-assay variation for CORT ranged from 10.1 to $13.8 \%$, and inter-assay variation was $12.43 \%$. Plasma volumes of the samples varied from 5 to $15 \mu \mathrm{L}$.

\section{Preliminary analyses}

Given that the sampling time of the first blood sample may affect baseline CORT levels, we used a regression analysis to account for this effect (supplementary material table A2). A similar analysis also allowed us to account for the possible effect of sampling day on CORT levels (supplementary material table A3). As we did not evidence a significant effect in these models, we used the measures of circulating CORT levels for subsequent analyses (see below).

\section{Statistical analyses}

We used a mixed-effect model to assess whether variation in circulating CORT levels significantly differed between individuals breeding at high and low elevations during the parental care stage. Our model included CORT levels (repeated measures at 3,15 and $30 \mathrm{~min}$ after capture) as the response variables; elevation (two levels), sex (two levels) and blood sample number (three levels) as explanatory variables; body condition index (residuals) as a co-variable; and individual identities as random effect (Zuur et al. 2007). The model included second-order interactions among sex, blood sample number and body condition with elevation.

Integrated CORT levels (sum total of the adrenocortical stress response) were obtained by calculating the area under the curve created when circulating CORT levels ( $y$-axis) were plotted against time ( $x$-axis) for each elevation. The baseline level of CORT was used as the base for the integrated CORT calculation (i.e., it was not included in the area under the curve; Breuner et al. 1999). The trapezoid rule was applied to avoid irregularities that could have resulted from interpolating a curve-linear fit to the stress response. A linear model was used to assess whether the integrated CORT levels significantly differed between high and low elevations. The model included the integrated CORT levels as a response variable, elevation (two levels) and sex (two levels) as explanatories variables and body condition (residuals) as a co-variable. Second-order interactions between body condition and elevation were also included in the model.

Statistical analyses were performed in R v. 3.3.2 (R Core Team 2016), using the lmer4 (Bates et al. 2015) R packages. An effect was considered significant when confidence intervals did not include zero.
Table 1 Mixed-effect model to assess the effect of elevation on the adrenocortical stress response in Rufous-collared sparrow $(n=22$ individuals; 3 blood samples per individual at 3, 15 and 30 min after capture; 66 total observations)

\begin{tabular}{lllll}
\hline Effect on CORT $(\mathrm{ng} / \mathrm{ml})$ & Estimate & SE & L 95\% CI & U 95\% CI \\
\hline Intercept & 7.98 & 3.56 & $\mathbf{1 . 5 0}$ & $\mathbf{1 4 . 4 6}$ \\
Elevation & -2.72 & 4.90 & -11.69 & 6.23 \\
Blood sample number 2 & 5.75 & 4.29 & -2.33 & 14.01 \\
Blood sample number 3 & 8.49 & 4.29 & $\mathbf{0 . 3 2}$ & $\mathbf{1 6 . 6 6}$ \\
Sex & -0.93 & 3.58 & -7.38 & 5.50 \\
Body condition & 0.63 & 1.77 & -2.54 & 3.82 \\
Elevation $\times$ blood sample & 14.22 & 6.28 & $\mathbf{2 . 1 7}$ & $\mathbf{2 6 . 0 9}$ \\
$\quad$ number 2 & & & & \\
Elevation $\times$ blood sample & 20.25 & 6.28 & $\mathbf{8 . 2 8}$ & $\mathbf{3 2 . 2 0}$ \\
$\quad$ number 3 & & & & \\
Elevation $\times$ body condition & 6.94 & 2.66 & $\mathbf{2 . 1 4}$ & $\mathbf{1 1 . 7 2}$ \\
$\quad$ Random effect & $\boldsymbol{\sigma}^{\mathbf{2}}$ & & & \\
Residual & 104.9 & & & \\
Individual identity & 20.68 & & & \\
\hline
\end{tabular}

Parameter estimates and SE (standard errors) for interaction terms were estimated relative to "low elevation" level in variable "elevation" and "male" level in variable "sex"

Bold numbers indicate intervals that did not include zero

$S E$ standard error, $L / U$ 95\% CI lower/upper bound for the $95 \%$ confidence interval

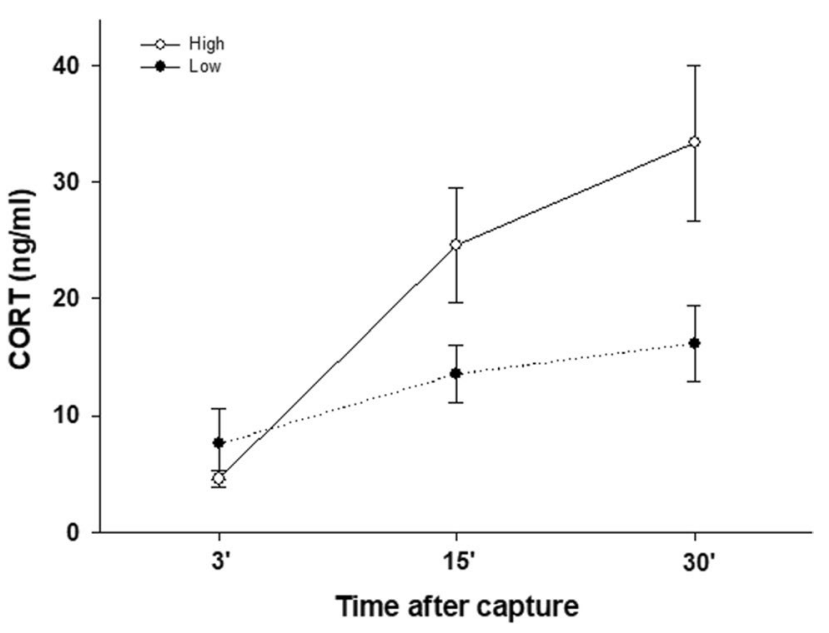

Fig. 2 Average baseline $(\mathrm{ng} / \mathrm{ml} \pm \mathrm{SE})$ and stress-induced CORT levels at 15 and $30 \mathrm{~min}$ after capture at high $(n=12)$ and low $(n=10)$ elevation populations in Rufous-collared Sparrow during parental care stage ("asterisk" indicate intervals that did not include zero)

\section{Results}

\section{Circulating CORT levels}

Baseline CORT levels tended to be higher at high elevation, but the variation is not significant (Table 1; Fig. 2). 


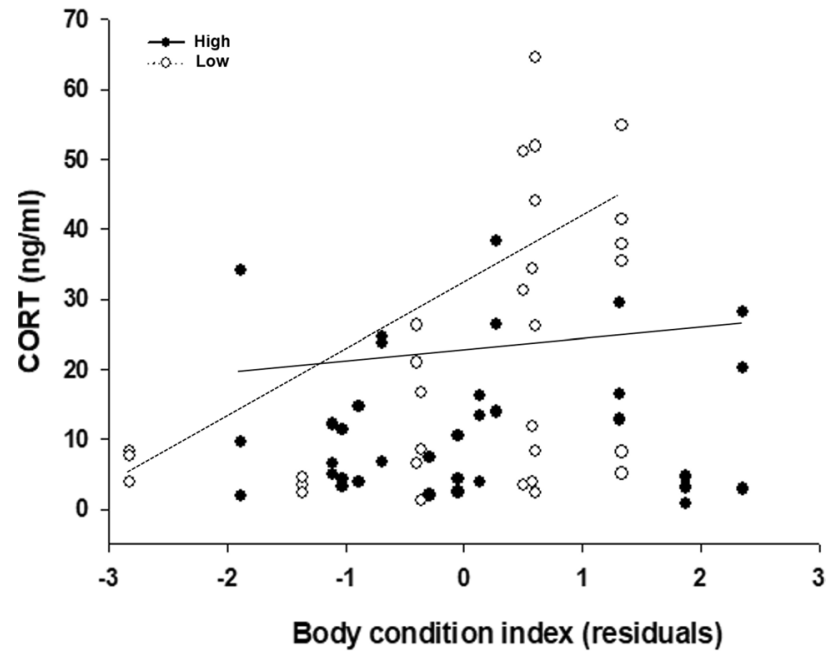

Fig. 3 Significant relationship between circulating CORT levels and body condition (residuals) in Rufous-collared sparrow ( $n=22$ individuals; 3 blood samples per individual at 3,15 and $30 \mathrm{~min}$ after capture; 66 total observations). Figure shows that individuals with higher body condition have higher CORT levels at low elevation $(\sim 500 \mathrm{~m})$. At high elevation $(\sim 2500 \mathrm{~m})$, relationship is not significant

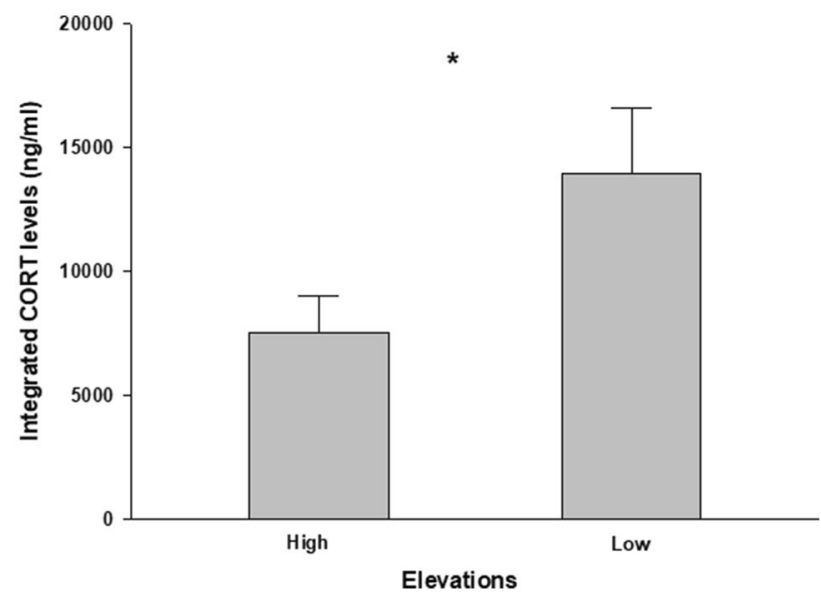

Fig. 4 Integrated CORT levels in Rufous-collared Sparrow $(n=22)$ during parental stage at high $(>2500$ m.a.s.l) and low $(<500$ m.a.s.l) elevations in central Chile. Figure shows that integrated CORT levels $(\mathrm{ng} / \mathrm{ml} \pm \mathrm{SE})$ are significantly greater at low elevation ("asterisk" indicate intervals that did not include zero)

However, individuals at higher elevation had considerably lower stress-induced CORT levels during the parental care stage than those breeding at low elevation (Table 1; Fig. 2). At low elevation, individuals with higher body condition had higher CORT levels than those with lower body condition (Table 1; Fig. 3). Sex had no effect on CORT levels (Table 1), and proportion of variance explained by individual identity in CORT levels was $20.68 \%$ (Table 1).

\section{Integrated CORT levels (sum total of the adrenocortical stress response)}

We found significant differences in integrated CORT levels between high and low elevations (Fig. 4). Specifically, we observed higher integrated CORT levels in individuals breeding at low elevation (Table 2). We also found a significant effect of body condition on integrated CORT levels at low elevation, with larger individuals showing higher integrated CORT levels. Sex had no effect on integrated CORT levels (Table 2).

\section{Discussion}

Baseline CORT levels did not significantly differ between populations at high and low elevations. However, significantly lower stress-induced CORT levels were observed during the parental care stage in birds breeding at high elevation, suggesting that birds may differ in the modulation of their adrenocortical stress response to cope with environmental gradients across elevations.

\section{Baseline CORT levels}

Baseline CORT levels observed were not affected by breeding elevation, body size and sex and were consistent with baseline concentrations of regulatory hormones (Dawson et al. 1992; Romero et al. 2009), which is a pattern that has also been observed in other passerine birds breeding at high elevation (Romero et al. 1997; Bears et al. 2003). The absence of significant differences in baseline CORT levels between birds breeding at different elevations, suggests that climatic conditions at high elevation are generally predictable (Romero et al. 2009). Under this context, the evolution of local strategies may help to cope with these environments without increase baseline CORT levels (McCarty et al. 1992; Grissom et al. 2007). For instance, intraspecific studies in the dark-eyed junco (Junco hyemalis) have shown that individuals at high elevations build subterranean nests (Bears 2002), match the duration of their reproductive period with the period of favorable weather and available food and produce fewer offsprings with better body conditions compared to low elevations birds (Bears et al. 2009). These adjustments in life-history traits permit individuals to cope with the often adverse environmental conditions at high elevation and this may be key to the maintenance of low baseline CORT levels during the breeding season.

Along with this, diversity of movement strategies as a response to weather conditions may also be linked to baseline CORT levels. Thus, birds that migrate at high elevation for breeding show higher baseline CORT levels during the breeding season compared to resident birds (Addis et al. 
Table 2 Fixed-effect model to assess the effect of elevation on integrated CORT levels in Rufous-collared sparrow $(n=22)$

\begin{tabular}{lrrrr}
\hline Effect on integrated CORT $(\mathrm{ng} / \mathrm{ml})$ & Estimate & SE & L 95\% CI & U 95\% CI \\
\hline Intercept & 8207.2 & 1767.2 & $\mathbf{4 4 6 0 . 8}$ & $\mathbf{1 1 , 9 5 3 . 5}$ \\
Elevation & 7021.7 & 2364.6 & $\mathbf{2 0 0 8 . 9}$ & $\mathbf{1 2 , 0 3 4 . 5}$ \\
Body condition index & 397.7 & 1224.2 & -2197.4 & 2992.8 \\
Sex & -1857.6 & 2490.6 & -7137.3 & 3422.2 \\
Elevation*Body condition & 5292.4 & 1805.8 & $\mathbf{1 4 6 4 . 3}$ & $\mathbf{9 1 2 0 . 4}$ \\
\hline
\end{tabular}

Parameter estimates and SE (standard errors) for interaction terms were estimated relative to "low elevation" level in variable "elevation" and "male" level in variable "sex"

Bold numbers indicate intervals that did not include zero

$S E$ standard error, $L / U 95 \%$ CI lower/upper bound for the $95 \%$ confidence interval
2011). In central Chile, Rufous-collared Sparrows remain at elevations over $1500 \mathrm{~m}$ year-round (Poblete et al. 2018), which means that increases in their baseline CORT levels may not be required, at least during the breeding season (McCarty et al. 1992; Grissom et al. 2007).

Weather conditions at high elevations may not be the principal cause of variation in baseline CORT levels during the breeding season. In fact, food availability and the presence of predators may be potentially more important natural stressors for wild animals (Romero 2004); nevertheless, no data regarding these aspects have been collected. In any case, the absence of elevated baseline CORT levels observed show that individuals can deal with the stressors of their local habitats, and it suggests that conditions at high elevations seem be not stressful to promote more elevated baseline CORT levels.

\section{Stress-induced CORT levels}

Subjects breeding at high elevation during the parental care stage had lower stress-induced CORT levels than individuals breeding at low elevation, suggesting that high-elevation individuals at can reduce their stress response, possibly in response to unpredictable events that have the potential to interrupt breeding and decrease reproductive success (e.g., low ambient temperatures, wind, rain, and snow; Wingfield et al. 1995). Similar variation in stress-induced CORT levels between elevations has been detected in birds in the Northern Hemisphere during parental care (see Silverin et al. 1997; O'Reilly and Wingfield 2001; Breuner and Hahn 2003). However, Clark et al. (2019) did not observe significant differences in stress-induced levels of CORT between pre-parental (early-breeding) and parental care (mid-breeding) in Rufous-collared Sparrow inhabiting at different elevations, including the same high-altitude population, and a lower-altitude population closer to the high-altitude population compared with this present study. Their finding suggests the general pattern of modulation of the adrenocortical stress response during the breeding season differed from that documented in birds of the Northern Hemisphere, where a marked seasonal down-regulation has been observed at high elevations compared to low elevations (Romero and Wingfield 2016). Our results, together with Clark et al. (2019), suggest environmental conditions at high elevations in central Chile might be severe enough for driving reduced adrenocortical stress response during parental care stage, but not for triggering a marked seasonal down-regulation of stress-induced CORT levels (Clark et al. 2019).

Adverse weather conditions at high elevation provide a potential explanation for the lower adrenocortical stress response observed at high elevations; however, this response may also be caused by other stressors, such as high predation pressure (Vitousek et al. 2014), low food availability (Jenni-Eiermann et al. 2008) or the interaction of those factors (Clinchy et al. 2004). Nevertheless, our results support a pattern of differentiation in the adrenocortical stress response during the parental care stage associated with the elevation of breeding sites, suggesting that different physiological strategies may have evolved in this species to cope with local environmental conditions.

\section{Sex, body condition and within-individual variation in circulating CORT levels}

We did not observe sex-specific differences in circulating CORT levels during the parental care stage associated with breeding site elevation (Table 1). Nevertheless, the seasonal comparison of stress-induced CORT levels between early breeding (pre-parental) and mid-breeding (parental) described by Clark et al. (2019) revealed that regardless of breeding elevation site, Rufous-collared Sparrow males had higher stress-induced CORT levels during pre-parental than during parental care period. Rufous-collared Sparrow males are territorial birds; consequently, sexual dimorphism in the stress-induced CORT levels during early breeding may be associated with territorial competition and mate attraction (Couve et al. 2016). However, males and females contribute equally to provisioning and raising the offspring and are thus exposed to similar energetic demands and conditions. 
Thus, sexes are unlikely to differ in their adrenocortical stress response with local environmental conditions during parental care stage, and hence, more research on the individual degree of parental care in these populations need to be collected to test this hypothesis (Wingfield et al. 1995).

We found positive and significant relationships between body condition and the stress-induced CORT levels at low elevation (Fig. 3), and these patterns were also detected by assessments of integrated CORT levels (Table 2). In both models, we noticed that the adrenocortical stress response was significantly lower at high elevation, but only larger individuals breeding at low elevations exhibited an increased adrenocortical stress response. Generally, the interplay between CORT levels and body condition is complex because individuals with high CORT levels may catabolize lipids, resulting in lower body condition (Fokidis et al. 2011). However, some studies have demonstrated that CORT stimulates foraging, which increases body condition and helps ameliorate the debilitating effects of environmental perturbation (Landys et al. 2004; Pecoraro et al. 2004). Therefore, individuals with large body condition have a greater tendency to elevate CORT levels during acute stress, likely because they have more energy demands and need to maintain their energy reserves (Dallman et al. 2004, 2007). Assessing how CORT acts on gluconeogenic metabolites (triglycerides, free glycerols, glucose) when this species copes with stress at different elevations is important for understanding the observed link between body size and the stress response. Interestingly, we found that $20.68 \%$ of the variation in stress-induced CORT levels was explained by individual identity, suggesting that individuals may differ extensively in their ability to modulate CORT levels (Ouyang et al. 2011). However, characterizing the degree of individual consistency in both baseline and stress-induced CORT levels is important for enhancing our understanding of how local environmental conditions affect adrenocortical responses (Williams 2008).

\section{Concluding remarks}

Our research provides an important insight into how Rufouscollared Sparrows have adjusted their patterns of circulating CORT levels during parental care in response to environmental conditions at different elevations in the Andes of central Chile. We emphasize the need to describe the life-history traits of these populations and the effects that other stressors, such as predation pressure and food availability, may have on the adrenocortical response in these environments, and to evaluate their consequences on survival and reproduction. This information is important for improving our understanding of the ecological and evolutionary mechanisms that modulate the variation in the adrenocortical stress response among populations inhabiting different elevations in the Southern Andes.
Acknowledgements We thank Cristobal Venegas, Nestor González and Pablo Veas for their collaboration during fieldwork. We thank Paula Castillo and two anonymous reviewers for valuable comments on an earlier draft of the manuscript. Funding was provided by grants from FONDECYT 1140548, grant ICM-P05-002, PFB-23 CONICYT-Chile, FONDECYT 3190111 to YP, FONDECYT 1200586 to PLG-G, and AFB-170008-CONICYT-Chile to RAV. All birds were captured and marked under the authority of the Chilean Agricultural and Livestock Service (Servicio Agrícola y Ganadero, SAG, permits7545) and the Corporación Nacional Forestal (CONAF), Chile. This research was carried out under the supervision of the Ethics Committee of the Science Faculty, Universidad de Chile.

Author contributions VG, YP and RAV conceived the idea and VG collected the data. YP analyzed the data and wrote the manuscript. PGG conduced the laboratory work and edited the manuscript. JCW provided assistance with the laboratory analysis and edited the manuscript. RAV supervised the research and edited the manuscript.

Data availability statement Should the manuscript be accepted, the data supporting the results will be archived in an appropriate public repository, such as Dryad or Figshare, and the data DOI will be included in the article.

Open Access This article is licensed under a Creative Commons Attribution 4.0 International License, which permits use, sharing, adaptation, distribution and reproduction in any medium or format, as long as you give appropriate credit to the original author(s) and the source, provide a link to the Creative Commons licence, and indicate if changes were made. The images or other third party material in this article are included in the article's Creative Commons licence, unless indicated otherwise in a credit line to the material. If material is not included in the article's Creative Commons licence and your intended use is not permitted by statutory regulation or exceeds the permitted use, you will need to obtain permission directly from the copyright holder. To view a copy of this licence, visit http://creativecommons.org/licenses/by/4.0/.

\section{References}

Addis EA, Davis JE, Miner BE, Wingfield JC (2011) Variation in circulating corticosterone levels is associated with altitudinal range expansion in a passerine bird. Oecologia 167:369-378. https:// doi.org/10.1007/s00442-011-2001-5

Barria I, Carrasco J, Casassa G, Barria P (2019) Simulation of longterm changes of the equilibrium line altitude in the central chilean andes mountains derived from atmospheric variables during the 1958-2018 period. Front Environ Sci. https://doi.org/10.3389/ fenvs.2019.00161

Bates D, Mächler M, Bolker B, Walker S (2015) Fitting Linear MixedEffects Models Using lme4. J Stat Softw 67:1-48. https://doi. org/10.18637/jss.v067.i01

Bears H, Smith JNM, Wingfield JC (2003) Adrenocortical sensitivity to stress in Dark-eyed Juncos (Junco hyemalis oregonus) breeding in low and high elevation habitat. Ecoscience 2:127-133. https:// doi.org/10.1080/11956860.2003.11682758

Bears H (2002) How and why a small songbird, the Oregon Junco (Junco hyemalis oregonus), breeds over a steep eleva- tion gradient: Shifting life-histories, adaptations, and costs and benefits with elevation. M.Sc. thesis, University of British Columbia, Vancouver, British Columbia

Bears H, Martin K, White GC (2009) Breeding in high-elevation habitat results in shift to slower life-history strategy within a 
single species. J Anim Ecol 78:365-375. https://doi.org/10.111 1/j.1365-2656.2008.01491.x

Bobby Fokidis H, Hurley L, Rogowski C et al (2011) Effects of captivity and body condition on plasma corticosterone, locomotor behavior, and plasma metabolites in curve-billed thrashers. Physiol Biochem Zool 84:595-606. https://doi.org/10.1086/662068

Bonier F, Martin PR, Moore IT, Wingfield JC (2009) Do baseline glucocorticoids predict fitness? Trends Ecol Evol 24:634-642. https ://doi.org/10.1016/j.tree.2009.04.013

Boyle WA (2017) Altitudinal bird migration in North America. Auk 134:443-465. https://doi.org/10.1642/auk-16-228.1

Breuner CW, Hahn TP (2003) Integrating stress physiology, environmental change, and behavior in free-living sparrows. Horm Behav 43:115-123. https://doi.org/10.1016/S0018-506X(02)00020-X

Breuner CW, Wingfield JC, Romero LM (1999) Diel rhythms of basal and stress-induced corticosterone in a wild, seasonal vertebrate, Gambel's white-crowned sparrow. J Exp Zool 284:334-342. https ://doi.org/10.1002/(SICI)1097-010X(19990801)284:3\%3c334 ::AID-JEZ11\%3e3.0.CO;2-\#

Burger F, Brock B, Montecinos A (2018) Seasonal and elevational contrasts in temperature trends in Central Chile between 1979 and 2015. Glob Planet Change 162:136-147. https://doi.org/10.1016/j. gloplacha.2018.01.005

Busch DS, Addis EA, Clark AD, Wingfeld JC (2010) Disentangling the efects of environment and life-history stage on corticosterone modulation in Costa Rican Rufous-collared Sparrows, Zonotrichia capensis costaricensis. Physiol Biochem Zool 83:87-96. https:// doi.org/10.1086/648488

Busch DS, Sperry TS, Peterson E et al (2008) Impacts of frequent, acute pulses of corticosterone on condition and behavior of Gambel's white-crowned sparrow (Zonotrichia leucophrys gambelii). Gen Comp Endocrinol 158:224-233. https://doi.org/10.1016/j. ygcen.2008.07.010

Chapman FM (1940) The post-glacial history of Zonotrichia capensis. B Am Mus Nat Hist 77:381-438. https://www.hdlhandlen et $/ 2246 / 876$

Clark AD, Addis EA, Vásquez RA, Wingfield JC (2019) Seasonal modulation of the adrenocortical stress responses in Chilean populations of Zonotrichia capensis. J Ornithol 160:61-70. https://doi. org/10.1007/s10336-018-1589-1

Clinchy M, Zanette L, Boonstra R, Wingfield JC, Smith JN (2004) Balancing food and predator pressure induces chronic stress in songbirds. Proc R Soc B Biol Sci 271:2473-2479. https://doi. org/10.1098/rspb.2004.2913

Couve E, Vidal CF, Ruiz J (2016) Aves de Chile, sus islas oceánicas y península antártica. FS Editorial, Punta Arenas

Dallman MF, Akana SF, Strack AM, Scribner KS, Pecoraro N et al (2004) Chronic stress-induced effects of corticosterone on brain: direct and indirect. Ann N Y Acad Sci 1018:141-50

Dallman MF, Warne JP, Foster MT, Pecoraro NC (2007) Glucocorticoids and insulin both modulate caloric intake through actions on the brain. J Physiol 583:431-436. https://doi.org/10.1113/jphys iol.2007.136051

Dawson WR, Carey C, Hof TJV (1992) Metabolic aspects of shivering thermogenesis in Passerines during Winter. Ornis Scand. https:// doi.org/10.2307/3676664

Di Castri F, Hajek E (1976) Bioclimatología de Chile. Editorial Universidad Católica de Chile

Eikenaar C, Müller F, Leutgeb C et al (2017) Corticosterone and timing of migratory departure in a songbird. Proc R Soc B Biol Sci. https ://doi.org/10.1098/rspb.2016.2300

Grissom N, Iyer V, Vining C, Bhatnagar S (2007) Corrigendum to "The physical context of previous stress exposure modifies hypothalamic-pituitary-adrenal responses to a subsequent homotypic stress." Horm Behav 51:665. https://doi.org/10.1016/j.yhbeh .2007.03.001
González-Goméz PL, Merrill L, Ellis VA, Venegas C, Pantoja JI, Vásquez RA, Wingfeld JC (2013) Breaking down seasonality: androgen modulation and stress response in a highly stable environment. Gen Comp Endocrinol 191:1-12. https://doi. org/10.1016/j.ygcen.2013.05.007

Jenni-Eiermann S, Glaus E, Grüebler M, Schwabl H, Jenni L (2008) Glucocorticoid response to food availability in breeding barn swallows (Hirundo rustica). Gen Comp Endocr 155:558-565. https://doi.org/10.1016/j.ygcen.2007.08.011

Landys MM, Ramenofsky M, Guglielmo CG, Wingfield JC (2004) The low-affinity glucocorticoid receptor regulates feeding and lipid breakdown in the migratory Gambel's white-crowned sparrow Zonotrichia leucophrys gambelii. J Exp Biol 207:143-154. https ://doi.org/10.1242/jeb.00734

Landys MM, Ramenofsky M, Wingfield JC (2006) Actions of glucocorticoids at a seasonal baseline as compared to stress-related levels in the regulation of periodic life processes. Gen Comp Endocrinol 148:132-149. https://doi.org/10.1016/j.ygcen.2006.02.013

Lopez-Calleja MV (1995) Dieta de Zonotrichia capensis (Emberizidae) Y Diuca diuca (Fringillidae): efecto de la variación estacional de los recursos tróficos y la riqueza de aves granívoras en Chile central. Rev Chil Hist Nat 68:321-331

LormÉe H, Jouventin P, Trouve C, Chastel O (2003) Sex-specific patterns in baseline corticosterone and body condition changes in breeding red-footed boobies Sula sula. Ibis 145:212-219. https:// doi.org/10.1046/j.1474-919X.2003.00106.x

Loshchagina J, Tsvey A, Naidenko S (2018) Baseline and stressinduced corticosterone levels are higher during spring than autumn migration in European robins. Horm Behav 98:96-102. https://doi.org/10.1016/j.yhbeh.2017.12.013

McEwen BS, Wingfield JC (2003) The concept of allostasis in biology and biomedicine. Horm Behav 43:2-15. https://doi. org/10.1016/S0018-506X(02)00024-7

McCarty R, Konarska M, Stewart RE (1992) Adaptation to stress: a learned response? In: Kvetnansky R et al (eds) Stress: neuroendocrine and molecular approaches. Gordon and Breach, NY, pp $521-535$

Miller AH, Miller VD (1968) The behavioral ecology and breeding biology of the andean sparrow, Zonotrichia Capensis. Caldasia 10:83-154

O'Reilly KM, Wingfield JC (2001) Ecological factors underlying the adrenocortical response to capture stress in Arctic-breeding shorebirds. Gen Comp Endocrinol 124:1-11. https://doi. org/10.1006/gcen.2001.7676

Ouyang JQ, Hau M, Bonier F (2011) Within seasons and among years: when are corticosterone levels repeatable? Horm Behav 60:559-564. https://doi.org/10.1016/j.yhbeh.2011.08.004

Pecoraro N, Reyes F, Gomez F et al (2004) Chronic stress promotes palatable feeding, which reduces signs of stress: feedforward and feedback effects of chronic stress. Endocrinology 145:3754-3762. https://doi.org/10.1210/en.2004-0305

Pereyra ME, Wingfield JC (2003) Changes in plasma corticosterone and adrenocortical response to stress during the breeding cycle in high altitude flycatchers. Gen Comp Endocrinol 130:222231. https://doi.org/10.1016/S0016-6480(02)00568-3

Poblete Y, Gutiérrez V, Cid V et al (2018) Intraspecific variation in exploratory behavior and elevational affinity in a widely distributed songbird. Oecologia 186:931-938. https://doi.org/10.1007/ s00442-018-4076-8

R Core Team (2016) R: A language and environment for statistical computing. R Foundation for Statistical Computing, Vienna, Austria. Retrieved from https://www.R-project.org/

Ramenofsky M (2011) Hormones in migration and reproductive cycles of birds. In: Norris DO, Lopez KH (eds) Hormones and reproduction of vertebrates. Academic Press, Elsevier, pp 205-237 
Romero LM (2004) Physiological stress in ecology: lessons from biomedical research. Trends Ecol Evol 19:249-255. https://doi. org/10.1016/j.tree.2004.03.008

Romero LM (2002) Seasonal changes in plasma glucocorticoid concentrations in free-living vertebrates. Gen Comp Endocrinol 128:1-24. https://doi.org/10.1016/S0016-6480(02)00064-3

Romero LM, Dickens MJ, Cyr NE (2009) The reactive scope model—a new model integrating homeostasis, allostasis, and stress. Horm Behav 55:375-389. https://doi.org/10.1016/j.yhbeh.2008.12.009

Romero LM, Wingfield JC (2016) Tempests, poxes, predators, and people: stress in wild animals and how they cope. Oxford University Press, Oxford

Romero LM, Reed JM, Wingfield JC (2000) Effects of weather on corticosterone responses in wild free-living passerine birds. Gen Comp Endocrinol 118:113-122. https://doi.org/10.1006/ gcen.1999.7446

Romero LM, Remage-Healey L (2000) Daily and seasonal variation in response to stress in captive starlings (Sturnus vulgaris): Corticosterone. Gen Comp Endocrinol 119:52-59. https://doi.org/10.1006/ gcen.2000.7491

Romero LM, Ramenofsky M, Wingfield JC (1997) Season and migration alters the corticosterone response to capture and handling in an Arctic migrant, the white- crowned sparrow (Zonotrichia leucophrys gambelii). Comp Biochem Phys B 116:71-77

Saavedra FA, Kampt SK, Fassnacht SR, Sibold JS (2018) Changes in Andes Mountains snow cover from MODIS data, 20002016. Cryosph Discuss 12:1027-1046. https://doi.org/10.5194/ tc-2017-72

Sapolsky RM, Romero LM, Munck AU (2000) How do glucocorticoids influence stress responses? Integrating permissive, suppressive, stimulatory, and preparative actions. Endocr Rev 21:55-89. https ://doi.org/10.1210/er.21.1.55

Silverin B, Arvidsson B, Wingfield J (1997) The adrenocortical responses to stress in breeding Willow Warblers Phylloscopus trochilus in Sweden: Effects of latitude and gender. Funct Ecol 11:376-384. https://doi.org/10.1046/j.1365-2435.1997.00097.x

Stehr A, Aguayo M (2017) Snow cover dynamics in Andean watersheds of Chile $\left(32.0-39.5^{\circ} \mathrm{S}\right)$ during the years 2000-2016. Hydrol Earth Syst Sci 21:5111-5126. https://doi.org/10.5194/ hess-21-5111-2017

Viale M, Nuñez MN (2011) Climatology of winter orographic precipitation over the subtropical central Andes and associated synoptic and regional characteristics. J Hydrometeorol 12:481-507. https ://doi.org/10.1175/2010JHM1284.1

Vitousek MN, Jenkins BR, Safran RJ (2014) Stress and success: individual differences in the glucocorticoid stress response predict behavior and reproductive success under high predation risk. Horm behav 66:812-819. https://doi.org/10.1016/j.yhbeh 2014.11.004

Wada H, Moore IT, Breuner CW, Wingfeld JC (2006) Stress responses in tropical sparrows: comparing tropical and temperate Zonotrichia. Physiol Biochem Zool 79:784-792. https://doi. org/10.1086/505509

Welcker J, Speakman JR, Elliott KH, Hatch SA, Kitaysky AS (2015) Resting and daily energy expenditures during reproduction are adjusted in opposite directions in free-living birds. Funct Ecol 29:250-258. https://doi.org/10.1111/1365-2435.12321

Williams TD (2008) Individual variation in endocrine systems: Moving beyond the "tyranny of the Golden Mean." Philos Trans R Soc B Biol Sci 363:1687-1698. https://doi.org/10.1098/rstb.2007.0003

Wingfield JC (2005) Flexibility in annual cycles of birds: implications for endocrine control mechanisms. J Ornithol 146:291-304. https ://doi.org/10.1007/s10336-005-0002-z

Wingfield JC (2013) The comparative biology of environmental stress: behavioural endocrinology and variation in ability to cope with novel, changing environments. Anim Behav 85:1127-1133. https ://doi.org/10.1016/j.anbehav.2013.02.018

Wingfield JC, O'reilly KM, Astheimer LB (1995) Modulation of the adrenocortical responses to acute stress in arctic birds: a possible ecological basis. Integr Comp Biol 35:285-294. https://doi. org/10.1093/icb/35.3.285

Wingfield JC, Suydam R, Hunt K (1994) The adrenocortical responses to stress in snow buntings (Plectrophenax nivalis) and Lapland longspurs (Calcarius lapponicus) at Barrow, Alaska. Comp Biochem Physiol Part C Comp 108:299-306. https://doi. org/10.1016/0742-8413(94)00030-E

Wingfield JC, Maney DL, Breuner CW et al (1998) Ecological bases of hormone-behavior interactions: the emergency life history stage. Am Zool 38:191-206. https://doi.org/10.1093/icb/38.1.191

Wingfield JC, Moore IT, Vásquez RA et al (2008) Modulation of the adrenocortical responses to acute stress in northern and southern populations of Zonotrichia. Ornit neotrop 19:241-251

Wingfield JC, Pérez JH, Krause JS et al (2017) How birds cope physiologically and behaviourally with extreme climatic events. Philos Trans R Soc B Biol Sci. https://doi.org/10.1098/rstb.2016.0140

Zuur AF, Ieno EN, Walker NJ et al (2007) Mixed effects models and extensions in ecology with R. Springer, New York

Publisher's Note Springer Nature remains neutral with regard to jurisdictional claims in published maps and institutional affiliations. 